\title{
Accuracy of determining specific parameters of the urban forest using remote sensing
}

\author{
Mariusz Ciesielski, \\ Krzysztof Sterenczak
}

\begin{abstract}
This paper reviews the current state of knowledge in the field of urban forest inventory and specific tree parameters derived by remote sensing. The paper discusses the possibilities and limitations of using remote sensing to determine the following characteristics of individual trees acquired during the inventory: position (coordinates), tree height, breast height diameter, tree crown parameters (crown span, height of tree crown basis, crown projection surface), health condition, and tree species. A total of 543 papers published in scientific databases (Scopus ${ }^{\oplus}$ and ScienceDirect ${ }^{\oplus}$ ) from the year 2000 to December 2017 have been analyzed; 86 of them were used for the review. The most important outcomes are: (a) the integration of many datasets, in particular spectral data (aerial images and satellite imageries) and structural data (LIDAR), allows the most complex use of remote sensing data and helps to improve the accuracy of parameter estimations as well as the correct identification of tree species; (b) the highest precision of measurement is characteristic of TLS, while ALS data has the largest operating system; (c) remote sensing data applications are associated with a large number of sophisticated processing on very large datasets using often proprietary elaborations; (d) the use of remote sensing data makes it possible to determine the characteristics of urban vegetation at various levels of detail and at different scales.
\end{abstract}

Keywords: Urban Forestry, Remote Sensing, Green Inventory, Laser Scanning, Hyperspectral Imaging, Satellite Imaging "heat island" effects, helping urban communities adapt to the effects of climate change by reducing heat stress (Takebayashi \& Moriyama 2007, Zupancic et al. 2015). Access to parks and nature can have a positive influence on physical activity (Kerr et al. 2012). Giles-Corti et al. (2005) proved that people who use green spaces in cities attain recommended levels of physicals activity more easily than non-users. Stigsdotter et al. (2010) found that people who lived beyond $1 \mathrm{~km}$ from a green zone (i.e., park) had a worse score on the dimensions of general and mental health and vitality, as well as higher levels of stress, than people who lived within $1 \mathrm{~km}$ of a green zone. Forest, parks and trees also influence real estate value and urban landscape aesthetics, and can play a role in storm water management and wind speed reduction. ratory diseases (Nowak \& Heisler 2010) Appropriate placement of trees can reduce fits to human well-being that trees bring to our cities. Trees and other vegetation play an important role in reducing air pollution, thereby decreasing the incidence of respi-

Department of Geomatics, Forest Research Institute, Sekocin Stary, Braci Lesnej 3, 05-090 Raszyn (Poland)

@ Mariusz Ciesielski (m.ciesielski@ibles.waw.pl)

Received: Dec 19, 2018 - Accepted: Aug 28, 2019

Citation: Ciesielski M, Sterenczak K (2019). Accuracy of determining specific parameters of the urban forest using remote sensing. iForest 12: 498-510. - doi: 10.3832/ifor3024-012 [online 2019-12-02]

Communicated by: Raffaele Lafortezza
As reported by Tate (1985), and Bickmore \& Hall (1983), inventory is the tool that can be used for the efficient management of greening in urban areas at various scales. A tree inventory collects accurate information on the condition, diversity and spatial distribution of trees in urban areas. Inventory results may constitute a starting point for a number of different analyses, such as variations in tree structure and species within urban areas (Sjöman et al. 2012), how trees shape the urban microclimate (Nowak et al. 2001), the impact of trees on reduction of air pollution and $\mathrm{CO}_{2}$ accumulation (McPherson et al. 1997, Nowak et al. 2006), the impact of greening on the value of real estates (Anderson \& Cordell 1988), and monitoring the risk of damage to vegetation and vegetation health (Maruthaveeran \& Yaman 2010, Kronenberg 2012).

Three types of inventory can be used to assess the vegetation in urban areas: partial, total, and random (statistical). Partial inventories are applied to selected urban areas, e.g., a park, a square or a tree avenue. A total inventory is a comprehensive description of all trees, groups of trees and bushes, including the identification of possible areas for new planting within the borders of streets, parks, squares, and other public spaces. Statistical methods are based on random selection and measure small parts of the area of interest, with sample plots being measured in the field (Escobedo \& Andreu 2008, Clarke et al. 
2013). The size of the field sampling area is selected in order to cover $5-10 \%$ of all trees or entire area, depending on spatial coverage and species variability. Inventories are usually carried out according to inventory key which include e.g. the list of tree species. Until now, inventories have been carried out mainly along roads, and less frequently for urban forests or parks (Thaiutsa et al. 2008, Sjöman et al. 2012). The main aims of the studies conducted in urban environment were the maintenance of road safety, the appropriate selection of species for planting, and the monitoring of changes in urban forestry (Keller \& Konijnendijk 2012).

The varying aims of urban resources monitoring, as well as the diversity of data recipients, results in a large number of parameters being acquired for each single tree. For example, research carried out using the Delphi method (a method used to identify the most reliable responses to questions from a group of experts in Scandinavia - Östberg et al. 2013) ended with 148 parameters assigned to single trees, all of which were considered to be important. Such a number of variables are difficult to acquire and harmonize for practical use. To increase ease of use, various attempts have been made to normalize inventory rules at the local or national level (Östberg et al. 2012a, UNRI 2010). As a result, with the help of practitioners, the ten most important tree parameters have been defined: genus and species, health condition, trunk position, class of damage hazard, presence of fruit bodies, disease treatments, conservation value, location (i.e., street/park), age class, and finally, stem circumference at 1 meter height at time of planting (Östberg et al. 2013). From an urban forest management perspective, information about tree height, crown parameters, and diameter at breast height (DBH) is also important (Saarinen et al. 2014, Lee et al. 2016).

The high costs associated with inventory data collection, as well as the wide range of acquired parameters and data applications, have increased the interest in finding alternative methods to perform urban greening inventories (Nielsen et al. 2014, Lee et al. 2016). To determine parameters for single trees or tree groups, or to acquire information regarding vegetation structure, remote sensing (RS) methods have been used with increasing frequency. The most commonly-used remote sensing methods include airborne (ALS), terrestrial (TLS) and mobile laser-scanning (MLS - Wu et al. 2013, Tanhuanpää et al. 2014), satellite imaging (Ardila et al. 2012), aerial photography (Xiao \& McPherson 2005), and more recently unmanned aerial vehicle technology (Putut Ash Shidiq et al. 2017). RS data can be expensive to acquire, and each of the aforementioned technologies has limitations and advantages. The aims of this paper are therefore: (i) to present a systematic overview of scientific publications in which RS methods were used to determine the most important parameters of single trees, in particular: location, species, health condition, tree height, $\mathrm{DBH}$, crown span (extent), height of tree crown base, and crown projection surface; (ii) to analyze the accuracy of individual parameters estimated through RS, and their viability as an alternative to field measurements; (iii) to specify which parameters of single trees can be determined using different spatial data, and how well they can be determined; (iv) to specify the opportunities and limitations associated with the various RS techniques; and ( $v$ ) to identify further research directions in the subject area.

\section{Material and methods}

The review of international literature presented here is based on the search results of two databases: Scopus ${ }^{\circledR}$ and Science Di- rect $^{\circledast}$. The literature search was carried out pursuant to the guidelines formulated by Pullin \& Stewart (2006). Three keywords were defined in a browser window, i.e., urban*, forest *, and inventory*, which were searched for in categories such as title, keywords, and abstract. The search was conducted for papers published between January 2000 and February 2017, and 543 records were retrieved. Search results were refined based on title and abstract content. Only those articles concerned with tree inventories in urban environment were selected for further analysis. Detailed analysis of the selected articles showed that nine of the studies were conducted using only field measurements. These articles were also removed from the analysis (Cumming et al. 2001, Brack 2006, Cumming et al. 2008, Thaiutsa et al. 2008, Sobczynski et al. 2011, Muthulingam \& Thangavel 2012, Clarke et al. 2013, Zygmunt et al. 2014, Strunk et al. 2016). The final database included 86 scientific papers. The selected papers fulfilled the following criteria: the study was published in English, the scope of the study was urban forestry, and the main focus of the study related to greening inventory methods at the level of individual trees and tree groups. The following information was recorded in the metadata table constructed for the search results: journal name; year of publication; the country where the research was carried out; the inventory methodology; and a detailed synopsis of the study content.

\section{Results}

\section{Overview of scientific papers}

The analyzed studies were carried out in 25 countries on all continents, except Africa and Antarctica. Most papers were performed in the United States (38 papers), followed by Germany ( 9 papers), Finland (8 papers), and the United Kingdom (5

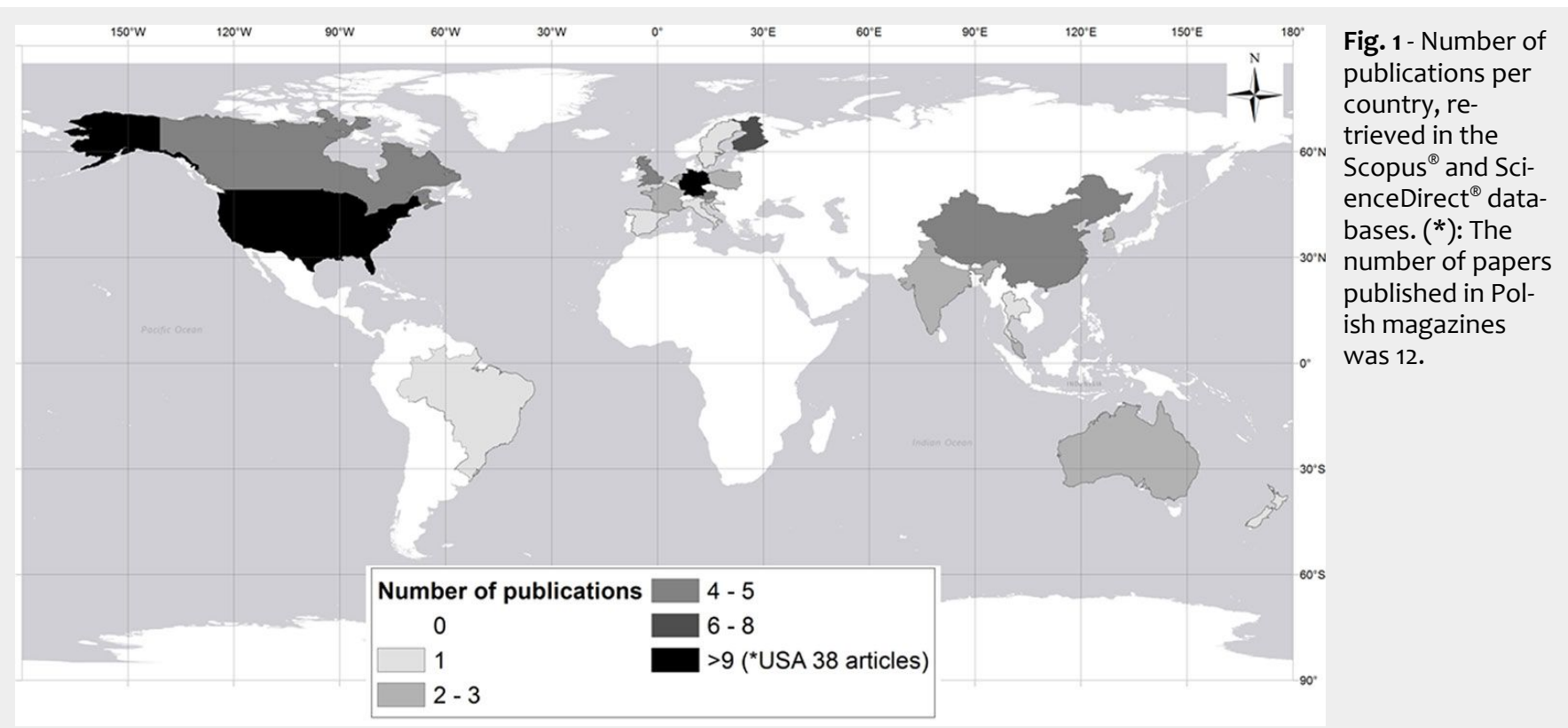


papers - Fig. 1). This distribution reflects the general number of studies performed on urban forestry worldwide. As reported by Bentsen et al. (2010), in the principal journal in this subject area, Urban Forestry and Urban Greening, 59\% of papers in the years 2000-2008 were performed in North America and Scandinavia.

The number of scientific papers whose focus is the determination of greening parameters has trended upward over time. The increase has been shown to be a result of improved access to RS data acquisition technologies; the growth of forestry-focused scientific research, the results of which can be used for analyses of greening in urbanized areas (see Fig. S1 in Supplementary material); and the increased availability of spatial data, resulting from the creation of free-of-charge spatial data repositories (Banskota et al. 2014, Chi et al. 2016, Wulder et al. 2016, Kempeneers \& Soille 2017). A diverse range of RS technologies have been developed to determine individual tree parameters and forest stand characteristics (Fig. 2). Since 2010, data from laser scanning has been acquired in multiple studies (ALS and TLS: 19 published studies). Researchers have also often performed analyses from the acquisition and combination of several sets of spatial data (data fusion, DF: 32 published studies).

Accuracy of tree attributes determined using remote sensing

\section{Position}

The identification of individual tree positions by means of RS requires two parameters to be defined precisely, i.e., individual tree detection and trunk location (X, Y Tab. 1). ALS data have predominantly been used for the detection of individual trees, and have been processed using the following algorithms: the tree climbing algorithm (Zhang \& Qiu 2012), individual tree detection (ITD - Holopainen et al. 2013), and watershed segmentation (crown-level fusion of hyperspectral imagery and ALS data Alonzo et al. 2014). Individual tree crowns have been delineated using canopy height models (Tanhuanpää et al. 2014), image segmentation (Phu La et al. 2015), local maxima algorithms (LMA), and the Koukoulas and Blackburn algorithm (KBA - Rahman \& Rashed 2015), as well as a variable window filter (Plowright et al. 2016). The accuracy of detection ranged from $69 \%$ (KBA method) to $99 \%$ (variable window filter method).

High spatial resolution satellite imaging is an alternative to laser scanning for tree species group detection. Ardila et al. (2012) achieved $70 \%$ to $92 \%$ accuracy in species detection, depending on the study area, with the use of QuickBird satellite imaging. The error of commissioning associated with this technique was equal to $26 \%$ (mainly for single trees with a crown area $\left.<15 \mathrm{~m}^{2}\right)$, and the error of omission ranged from $18 \%$ to $30 \%$. Apart from the method used, the

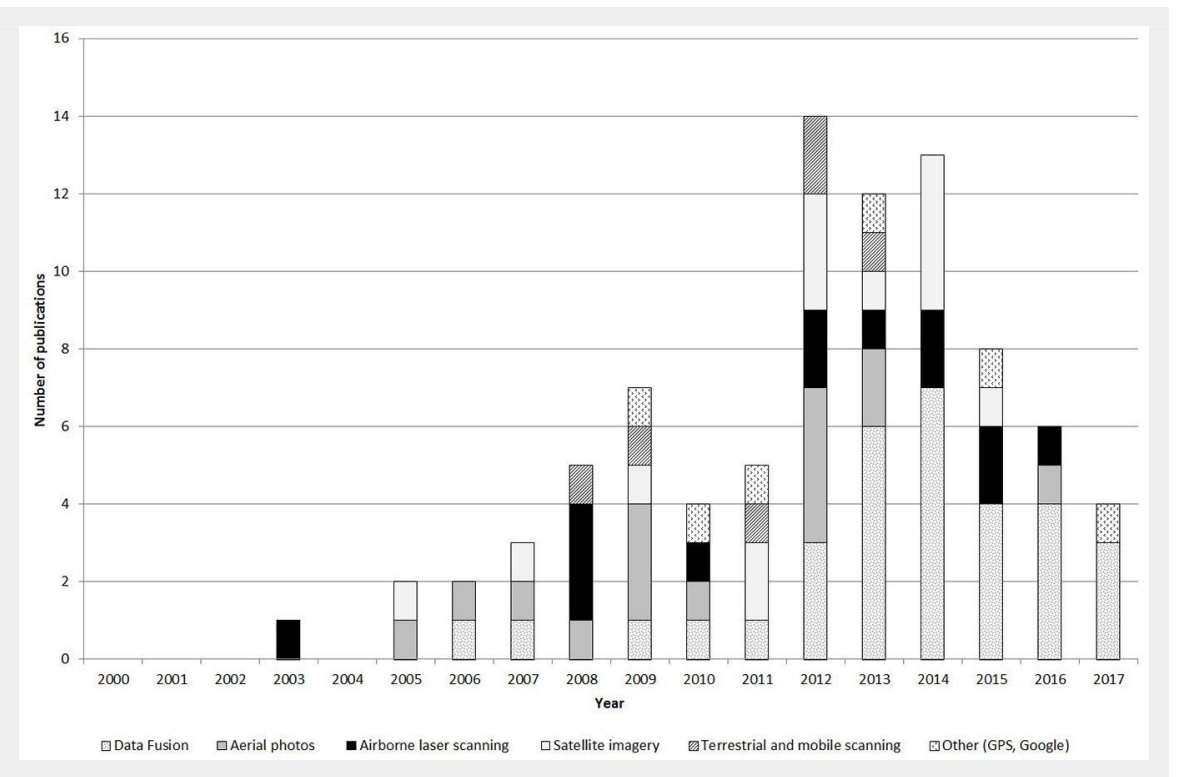

Fig. 2 - Number of publications retrieved from Scopus ${ }^{\oplus}$ and ScienceDirect ${ }^{\oplus}$ databases per year and the remote sensing technology used.

character of the research area also impacted on the reliability of results, which varied with, among other factors, dominant species type (deciduous/coniferous), tree age, and quality of reference data (Sterenczak 2013). Plowright et al. (2016), who achieved the most accurate detection results, used the variable window filter algorithm in their research, which, prior to that study, had mainly been applied to forest areas (Popescu et al. 2003, Sterenczak 2013), where the parameters of the tool were calibrated in accordance with species composition and age/height of the forest. In Plowright et al. (2016) research, the method was calibrated against a single species, but also indicated that it is possible to develop equations for other tree species and apply them in parallel. Rahman \& Rashed (2015) showed that combining the LMA and KBA methods generates more reliable results than using these methods separately. The improvement in results is due to the limitation of the KBA algorithm in identifying and measuring the height of individual trees and groups of trees, being overcome by the LBA algorithm which has the ability to identify individual trees with overlapping canopies. Tanhuanpää et al. (2014) pointed out that the time of data acquisition has an impact on the obtained results, in that if the reference data (field data) and RS data were obtained on different dates, some trees may have been removed, planted or replanted. In this case, attention should be paid to data cohesion. The main reasons for that are a wide range of species (many non-native species), and spatial/structural variability (e.g., single tree growth, varying light conditions, and tree shape modification by human activities). A large variation in the size and shape of tree crowns forces the user to choose between the algorithms generating too many or too few trees during segmentation.
The problem of reference data quality from GIS urban databases was emphasized by Plowright et al. (2016), who showed the importance of improving coordinate accuracy derived from RS databases, by correcting positional errors, and removing trees that may have been incorrectly recorded. Moreover, Tanhuanpää et al. (2014) pointed out that substantial problems in individual tree detection are caused by the diversity of tall objects in the urban environment, which confuse the algorithms used to detect vertices; for example, lamp posts, power lines, and tall vehicles in the streets. Such issues present different challenges for researchers involved in the detection of trees in urban environments, compared to studies that detect trees in forest areas (Tanhuanpää et al. 2014, Zhang et al. 2015). Ardila et al. (2012) pointed out that aerial images collected during leaf-off conditions are usually subject to geometric distortions that affect the accuracy of tree surface estimation, but are only occasionally used. They also emphasized that the urban environment is more diverse than forest areas; in forests, the picture is less complex and the adoption of specific parameters in Geographic Object-based Image Analysis (GEOBIA) generates results with a similar degree of accuracy in different areas. ITD methods are available and in general give acceptable results for urban greening inventories. ALS data are the most reliable, and multispectral data are adequate for this purpose. Integration of the various RS data, where possible, improves the accuracy of results. Most authors agreed that the urban environment is more complex that the forest environment, which causes many additional problems in the detection of individual trees.

Tompalski (2009) processed TLS data using the method of convex hulls generated 
Tab. 1 - Selected scientific publications reporting individual tree detection, tree height, DBH, and crown parameters. The research area, data set, method and accuracy are reported. (-): this variable was not specified; (n/d): this variable was specified but no error was given.

\begin{tabular}{|c|c|c|c|c|c|c|c|c|}
\hline Publication & $\begin{array}{l}\text { Study } \\
\text { Area }\end{array}$ & Data Set & Method & $\begin{array}{l}\text { Single tree } \\
\text { detection } \\
\text { rate }\end{array}$ & $\begin{array}{c}X, Y \\
\text { Coordinates } \\
\text { accurancy } \\
\text { and } \\
\text { precision }\end{array}$ & $\begin{array}{l}\text { Tree height } \\
\text { prediction } \\
\text { results }\end{array}$ & $\begin{array}{l}\text { Tree crown } \\
\text { parameters } \\
\text { prediction } \\
\text { results }\end{array}$ & $\begin{array}{l}\text { DBH } \\
\text { prediction } \\
\text { results }\end{array}$ \\
\hline $\begin{array}{l}\text { Shrestha \& } \\
\text { Wynne (2012) }\end{array}$ & US & $\begin{array}{l}\text { DF (ALS, satellite } \\
\text { imagery) }\end{array}$ & $\begin{array}{l}\text { Manual (acquiring } \\
\text { information from a } \\
\text { raster) }\end{array}$ & - & - & $\begin{array}{l}1.34 \mathrm{~m} \\
\text { (RMSE); } \\
0.89\left(\mathrm{R}^{2}\right)\end{array}$ & $\begin{array}{l}0.75 \text { (RMSE) } \\
0.9\left(\mathrm{R}^{2}\right)\end{array}$ & $\begin{array}{c}0.11 \text { (RMSE) } \\
0.82^{*}\left(\mathrm{R}^{2}\right)\end{array}$ \\
\hline $\begin{array}{l}\text { Lee et al. } \\
\text { (2016) }\end{array}$ & US & $\begin{array}{l}\text { DF (ALS, satellite } \\
\text { imagery) }\end{array}$ & $\begin{array}{l}\text { Regional } \\
\text { maxima,manual }\end{array}$ & - & - & $\begin{array}{l}1.64 \mathrm{~m} \\
\text { (RMSE); }\end{array}$ & $\begin{array}{l}1.07 \mathrm{~m} \\
\text { (RMSE) }\end{array}$ & $\begin{array}{l}0.10 \mathrm{~m} \\
(\mathrm{RMSE}) \\
0.88\left(\mathrm{R}^{2}\right)\end{array}$ \\
\hline $\begin{array}{l}\text { Zhang \& Qiu } \\
\text { (2012), Zhang } \\
\text { et al. 2015) }\end{array}$ & US & $\begin{array}{l}\text { DF (ALS, } \\
\text { hyperspectral } \\
\text { imagery) }\end{array}$ & Tree climbing algorithm & $93.5 \%$ & - & $\begin{array}{l}0.57-1.11 \mathrm{~m} \\
\text { (RMSE); } \\
0.93-0.98 \\
\left(\mathrm{R}^{2}\right)\end{array}$ & $\begin{array}{c}0.63-0.84 \\
\left(R^{2}\right)\end{array}$ & - \\
\hline $\begin{array}{l}\text { Phu La et al. } \\
\text { (2015) }\end{array}$ & US & $\begin{array}{l}\text { DF (ALS, } \\
\text { hyperspectral } \\
\text { imagery) }\end{array}$ & Image segmentation & $62.0-70.0 \%$ & - & $\begin{array}{c}0.45-0.97 \\
\left(R^{2}\right)\end{array}$ & $\begin{array}{c}0.26-0.96 \\
\left(R^{2}\right)\end{array}$ & - \\
\hline $\begin{array}{l}\text { Alonzo et al. } \\
\text { (2014) }\end{array}$ & US & $\begin{array}{l}\text { DF (ALS, } \\
\text { hyperspectral } \\
\text { imagery) }\end{array}$ & $\begin{array}{l}\text { Watershed } \\
\text { segmentation }\end{array}$ & $83 \%$ & - & - & - & - \\
\hline $\begin{array}{l}\text { Banzhaf \& } \\
\text { Kollai (2015) }\end{array}$ & Germany & $\begin{array}{l}\text { DF (Orthophotos, } \\
\text { ALS) }\end{array}$ & $\begin{array}{l}\text { Geographic Object } \\
\text { Based Image Analysis } \\
\text { (OBIA) }\end{array}$ & $n / d$ & - & - & - & - \\
\hline $\begin{array}{l}\text { lovan et al. } \\
\text { (2008) }\end{array}$ & France & $\begin{array}{l}\text { DF (Orthophotos, } \\
\text { ALS) }\end{array}$ & $\begin{array}{l}\text { SVM / obust region } \\
\text { growing algorithm based } \\
\text { on tree-shape criteria }\end{array}$ & $78 \%$ & - & - & - & - \\
\hline $\begin{array}{l}\text { Saarinen et } \\
\text { al. (2014) }\end{array}$ & Finland & DF (ALS, TLS) & $\begin{array}{l}\text { Watershed } \\
\text { segmentation/Visual } \\
\text { interpretation }\end{array}$ & - & $\begin{array}{l}0.1 \mathrm{~m} \\
\text { (bias) }\end{array}$ & $\begin{array}{l}-1.0-1.0 \mathrm{~m} \\
\text { (difference) }\end{array}$ & - & $\begin{array}{l}0.39-0.76 \mathrm{~m} \\
\quad \text { (RMSE) }\end{array}$ \\
\hline $\begin{array}{l}\text { Tompalski } \\
\text { (2013) }\end{array}$ & Poland & $\begin{array}{l}\text { DF (TLS, ALS, } \\
\text { satellite imagery) }\end{array}$ & $\begin{array}{l}\text { Voxel-Based Method } \\
\text { /Convex } \\
\text { hall/LasBoundary } \\
\text { algorithm }\end{array}$ & - & - & $\begin{array}{l}1.77 \mathrm{~m} \\
(\mathrm{RMSE}) ; \\
0.94\left(\mathrm{R}^{2}\right)\end{array}$ & $\begin{array}{c}0.46-0.56 \\
\left(R^{2}\right)\end{array}$ & $\begin{array}{l}0.03 \mathrm{~m} \\
(\sigma)\end{array}$ \\
\hline $\begin{array}{l}\text { Holopainen et } \\
\text { al. (2013) }\end{array}$ & Finland & DF (ALS, TLS, MLS) & $\begin{array}{l}\text { Individual Tree } \\
\text { Detection/ cylinder } \\
\text { fitting }\end{array}$ & $\begin{array}{l}73.29- \\
79.22 \%\end{array}$ & $\begin{array}{l}0.44-1.57 \mathrm{~m} \\
\text { (RMSE) }\end{array}$ & - & - & - \\
\hline $\begin{array}{l}\text { Plowright et } \\
\text { al. (2016) }\end{array}$ & Canada & ALS & Variable window filter & $99.0 \%$ & - & $\begin{array}{l}1.09 \mathrm{~m} ; \\
0.93\left(R^{2}\right)\end{array}$ & - & - \\
\hline $\begin{array}{l}\text { Rahman \& } \\
\text { Rashed (2015) }\end{array}$ & US & ALS & KBA/LMA & $69.0-73.0 \%$ & - & $\begin{array}{c}0.81-0.87 \\
\left(R^{2}\right)\end{array}$ & - & - \\
\hline $\begin{array}{l}\text { Tanhuanpää } \\
\text { et al. (2014) }\end{array}$ & Finland & ALS & $\begin{array}{l}\text { Watershed } \\
\text { segmentation }\end{array}$ & $88.8 \%$ & $\begin{array}{l}0.25 \mathrm{~m} \\
\text { (bias) }\end{array}$ & $\begin{array}{l}1.27 \mathrm{~m} \\
\text { (RMSE) }\end{array}$ & - & $\begin{array}{l}0.07 \mathrm{~m} \\
\text { (RMSE) }\end{array}$ \\
\hline $\begin{array}{l}\text { Wu et al. } \\
(2013)\end{array}$ & China & TLS/MLS & Voxel-Based Method & $98.5-100 \%$ & - & - & $\begin{array}{l}0.92-0.93 \\
\left(R^{2}\right)\end{array}$ & $\begin{array}{l}0.03 \mathrm{~m} \\
\text { (RMSE); } \\
0.87\left(\mathrm{R}^{2}\right)\end{array}$ \\
\hline $\begin{array}{l}\text { Vonderach et } \\
\text { al. (2012) }\end{array}$ & Germany & TLS/MLS & Voxel-Based Method & - & - & $\begin{array}{c}0.5-1.6 \mathrm{~m} \\
\text { (difference) }\end{array}$ & - & $\begin{array}{c}-0.01-0.08 \\
m\end{array}$ \\
\hline $\begin{array}{l}\text { Moskal \& } \\
\text { Zheng (2012) }\end{array}$ & US & TLS/MLS & Point Cloud Slicing (PCS) & - & - & $\begin{array}{l}0.75 \mathrm{~m} \\
(\mathrm{RMSE}) ; \\
0.57\left(\mathrm{R}^{2}\right)\end{array}$ & - & $\begin{array}{l}91.0 \% ; 0.09 \\
\text { m (RMSE) }\end{array}$ \\
\hline $\begin{array}{l}\text { Rutzinger et } \\
\text { al. (2011) }\end{array}$ & Holland & TLS/MLS & 3D Modelling & $86.0 \%$ & - & $n / d$ & - & - \\
\hline $\begin{array}{l}\text { Tompalski } \\
\text { (2009) }\end{array}$ & Poland & TLS/MLS & Convex hulls & - & $\begin{array}{l}0.57 \mathrm{~m} \\
\text { (bias) }\end{array}$ & $\begin{array}{l}2.27 \text { and } \\
1.58 \mathrm{~m}(\sigma)\end{array}$ & $\begin{array}{l}-0.35 \mathrm{~m} \\
\text { (bias) }\end{array}$ & - \\
\hline $\begin{array}{l}\text { Ardila et al. } \\
(2012)\end{array}$ & Holland & Satellite imagery & $\begin{array}{l}\text { Geographic Object } \\
\text { Based Image Analysis } \\
\text { (OBIA) }\end{array}$ & $70-82 \%$ & - & - & - & - \\
\hline $\begin{array}{l}\text { Morgenroth \& } \\
\text { Gomez (2014) }\end{array}$ & $\begin{array}{l}\text { New } \\
\text { Zealand }\end{array}$ & $\begin{array}{l}\text { Digital } \\
\text { photographs }\end{array}$ & $\begin{array}{l}\text { Photogrammetric } \\
\text { stereo-measurements } \\
\text { conducted on digital } \\
\text { photographs taken on } \\
\text { the ground level }\end{array}$ & - & - & $0.1 \mathrm{~m}$ & - & $\begin{array}{l}0.03 \mathrm{~m} \\
\text { (bias) }\end{array}$ \\
\hline $\begin{array}{l}\text { Patterson et } \\
\text { al. (2011) }\end{array}$ & US & $\begin{array}{l}\text { Digital } \\
\text { photographs }\end{array}$ & $\begin{array}{l}\text { Manual measurements } \\
\text { in UrbanCrowns } \\
\text { software application }\end{array}$ & - & - & $n / d$ & $n / d$ & $n / d$ \\
\hline
\end{tabular}


at certain heights over the ground surface, and found the position of trees was set with an average error of $0.57 \mathrm{~m}$. More accurate results, with an average error of $0.10 \mathrm{~m}$, were obtained by Saarinen et al. (2014), who applied a visual interpretation method. Holopainen et al. (2013) compared the accuracy of determining tree trunk positional coordinates by TLS, MLS, and ALS. The results of the study showed that TLS data reproduced tree position with the best accuracy, where root mean square error (RMSE) was equal to $0.12 \mathrm{~m}$; whereas MLS data had a RMSE $=0.36 \mathrm{~m}$, and ALS data a RMSE $=1.27 \mathrm{~m}$. In the opinion of Holopainen et al. (2013), the error in tree position estimates based purely on ALS data is caused by the variation in crown shapes as well as the age of trees, which influences the size of the crown. The accuracy of tree positions determined from ALS data in urban environments is similar to the results obtained in forest areas by Kaartinen et al. (2012). The results of these studies show that one advantage of TLS and MLS data is the high accuracy with which tree position can be determined, even for those growing under dominant trees. ALS data is associated with larger errors, but the cost of data acquisition is much smaller than for MLS and TLS. ALS data are abundant and easy to access. MLS and ALS have high operationality. The TLS technique is more suited to small area inventories that require very high precision.

\section{Tree height}

There are three methods that can be used to extract information on tree height from RS data: (i) point cloud processing of data collected using active LiDAR technology (ALS, MLS and TLS); (ii) stereophotogrammetric measurements extracted from digital photographs taken at ground level; and (iii) 3D point cloud processing using airborne digital image matching. A precise digital terrain model, which can be created from ALS data, is a requirement of the latter method. So far, studies using 3D point cloud processing are rare.

The accuracy of tree height measurements retrieved from ALS depends on factors such as flight and data acquisition parameters, tree species being measured, data processing technology, and the method used for individual tree identification (Sterenczak et al. 2008). Tanhuanpää et al. (2014) applied an ALS point cloud with a density greater than $20 \mathrm{pts} \mathrm{m}^{-2}$. The accuracy achieved with the watershed segmentation method (RMSE $=1.08 \mathrm{~m}$ ) was comparable to the accuracy achieved by Rahman \& Rashed (2015) using the KBA method (RMSE $=1.08 \mathrm{~m})$, and the LMA method (RMSE $=1.3 \mathrm{~m}$ ). The LMA method was also used by Plowright et al. (2016), who achieved a mean error in height measurements equal to $1.09 \mathrm{~m}$, using a point cloud density equal to $25 \mathrm{pts} \mathrm{m}^{-2}$. Zhang et al. (2015) performed treetop detection using a constrained tree climbing algorithm, and achieved accuracies ranging from 0.47 to $1.11 \mathrm{~m}$ (RMSE). The relatively low error achieved in Zhang et al. (2015) may result from the fact that most trees in the study area were broadleaved with a wider top than conifers, which increased the probability that laser pulses hit the treetops. Shrestha \& Wynne (2012) presented height measurements for 9 tree species with an average RMSE value of $1.34 \mathrm{~m}$.

Vonderach et al. (2012) showed that height determined from TLS data is regularly underestimated. The differences in TLS measurements and terrestrial measurements fall within a range of 0.50 to $1.50 \mathrm{~m}$. Similar results, with an RMSE equal to $1.77 \mathrm{~m}$, were achieved by Tompalski (2013). With MLS, Wu et al. (2013) determined tree heights with an $R^{2}$ coefficient of 0.9 , and an RMSE equal to $0.18 \mathrm{~m}$. Morgenroth \& Gomez (2014) used a point cloud generated from ground level digital photographs taken from multiple positions. In their studies, tree height estimates contained an error of $0.10 \mathrm{~m}$ (2.59\%).

The accuracy of tree height measurements using ALS data depends not only on data processing methods but also on the tree species, and is also dependent on the quality of field-based measurements (Mielcarek et al. 2018). Their results show that when relatively high point density ALS data are used, the error in height estimation is greater for some deciduous species (e.g., oaks) than for conifers and alder. This is not related to the reliability of ALS measurements, but rather to the difficulty associated with precisely measuring the height of old trees, such as oaks. Oak crowns are usually irregular and complex; therefore, it is difficult to clearly determine the top of the tree from the ground. Measuring the height of conifers is easier and more precise due to their compact and cone-shaped crowns. Mielcarek et al. (2018) also noted that errors for deciduous trees increased slightly with increasing tree height. Such a tendency was not found in coniferous and alder trees. Further, ALS data itself can influence height measurements. Morsdorf et al. (2008) proved that the underestimation of tree heights by ALS increased by approximately $0.3 \mathrm{~m}$ with an increase from 500 to $900 \mathrm{~m}$ flying altitude. Yu et al. (2004) showed that tree height could be measured more accurately with a large footprint, because the laser pulse has a higher probability of hitting the top of the trees. Tanhuanpää et al. (2014) and Orka \& Bollandsås (2010) determined that ALS should be collected during the leaf-on season, because the data generates less noise and lower errors than leaf-off data, which can be explained by the denser canopy under leaf-on conditions. Tompalski (2013) showed that there was no relation between the height of a tree measured using TLS and the distance of a tree from the scanner, or the height of a tree and other features, such as the type and number of points. Contrasting results were achieved in a for- est area by Olofsson et al. (2014), who proved that the error in tree height measurements depends on distance to the scanner. According to Tompalski (2013), scanning in unfavorable terrain with a high density of trees does not prevent the acquisition of exact tree height values. Tompalski (2013) also indicates that scanning should be performed during the leaf-off period, and the number and distribution of scanning positions should be properly arranged.

\section{Diameter at breast height}

Previous studies have reported three different approaches for the determination of the diameter at breast height (DBH). The first involves the use of descriptive variables from ALS data, the second uses TLS and MLS data and the third is based on a cloud of points that are generated from photographic images. Shrestha \& Wynne (2012) determined DBH with an indirect method using two types of ALS variable. DBH determined from tree crown size resulted in $\mathrm{R}^{2}$ coefficients of 0.82 for all trees, 0.84 for deciduous species, and 0.74 for coniferous trees. Assessing DBH based on average height resulted in inferior $\mathrm{R}^{2}$ coefficients, i.e., 0.72 for all trees, 0.76 for deciduous species, and 0.54 for coniferous species. By constructing convex hulls from TLS data, Tompalski (2009) achieved DBH estimates with an RMSE of $0.013 \mathrm{~m}$ and a standard deviation of $0.03 \mathrm{~m}$. Using a point cloud slicing (PCS) method based on voxel data structure and circle fitting, Wu et al. (2013), Moskal \& Zheng (2012), and Vonderach et al. (2012), achieved accuracies in DBH estimations of $0.03 \mathrm{~m}$ (RMSE), $0.09 \mathrm{~m}$ (RMSE), and -0.01-0.08 m (bias), respectively. Results achieved by Vonderach et al. (2012) are similar to Tompalski (2013). With a point cloud constructed from a series of digital photographs, Morgenroth \& Gomez (2014) calculated a DBH for an individual tree with an error of $0.03 \mathrm{~m}$. As Wu et al. (2013) emphasized, despite the high quality of results, TLS data have limited application in urban areas, due to the limited coverage that can be achieved from TLS devices. This strongly contrasts with ALS data collection methods. According to Tompalski (2013), the circle fitting method is the most reliable, because it works better when trunk cross-sections are only partially covered by points. However, a large number of alternative solutions exist in the literature that have not yet been tested in an urban environment (Pueschel et al. 2013). Results can also be improved by performing single or multistation scans, which construct more accurate reproductions of breast height (Tompalski 2013).

\section{Tree crown}

The subject of determining the parameters of the crown is often not addressed in scientific publications. In studies where this issue is considered, parameters were estimated directly or indirectly from ALS, MLS, 
or TLS data, or from field-based photos. Using ALS data, Shrestha \& Wynne (2012) determined crown spans with an $\mathrm{R}^{2}$ coefficient of 0.90. Crown diameters were calculated in that study from ALS data using the formula: $2 \cdot$ radius $=V$ crown area $/ \pi$, with a RMSE of $0.75 \mathrm{~m}$. In the same study, a lower correlation $\left(R^{2}=0.75\right)$ was achieved by calculating maximum heights and crown span values from field measurements. Zhang et al. (2015) using ALS data identified the height of tree crown bases with a correlation ( $r$ ) value of 0.63-0.84, and a crown span with $R^{2}$ values ranging from 0.7 to 0.84 . With ground level laser scanning, Tompalski (2013) calculated crown projection surfaces with an $\mathrm{R}^{2}$ coefficient of 0.81 . Tompalski (2009) determined crown base height with a mean error of $-0.35 \mathrm{~m}$. MLS data was used by Wu et al. (2013) to determine crown spans with $R^{2}$ values ranging from 0.92 to 0.93. Abd-Elrahman et al. (2010) explored the effectiveness of using different digital camera models to assess crown span and crown base height. Based on photographs, the errors in crown span and crown base height values were determined to be $0.4 \mathrm{~m}$ and $0.05 \mathrm{~m}$, respectively. Accurate calculation of the crown size parameter is vital for determining crown coverage, which is one of the parameters that characterize the urban ecosystem. According to previous studies, crown size estimated from ALS data is usually less accurate than tree height (Gill et al. 2000, Popescu et al. 2003). Low accuracy can result from crown shape, low scanning density and the overlap of the crowns of adjacent trees (Zhang et al. 2015). The results obtained by Zhang et al. (2015) were promising, and show that the accuracy of key parameter estimates, such as base height and depth of the crown, may be related to the accuracy of tree height estimates. This is important because, even during field measurements, it is difficult to measure such parameters, especially in densely forested areas. Zhang et al. (2015) suggested that a higher scanning density may lead to higher accuracy, as the probability of hitting lower branches will increase.

\section{Health condition}

The majority of studies concerning vegetation health condition were performed using aerial (including hyperspectral) and satellite imagery. A number of authors ( $\mathrm{Ho}$ lopainen et al. 2006, Hanou 2010, Hu et al. 2014, Zhang et al. 2014, Pontius et al. 2017) compared the health condition of healthy, diseased and dead trees with vegetation indices, or determined relationships between the variables obtained from RS data and biophysical variables (e.g., defoliation and discoloration). Malthus \& Younger (2000) determined the correlations between an overall tree condition index (OTC), defoliation, and selected vegetation indices, such as the Normalized Difference Vegetation Index (NDVI), the Green Nor- malized Difference Vegetation Index (gNDVI), and the red edge position (REP). A significant correlation was only observed between the OTC and the gNDVI, and the OTC and the REP. The authors did not find any relation between the defoliation and vegetation indices. Xiao \& McPherson (2005) carried out an analysis of tree health at the two scales of individual tree and individual pixels. The authors classified trees as healthy if the ratio of healthy pixels determined by NDVI and the total number of pixels was higher than $70 \%$; otherwise, trees were classified as unhealthy or dead. The total accuracy of classification on the level of individual trees was $88.9 \%$, i.e., $86 \%$ for deciduous trees and $91.0 \%$ for coniferous trees. Holopainen et al. (2006) used aerial color infrared imagery to assess the volume of trees damaged as a result of drought. They achieved their results by visual interpretation of the images. Jarocinska et al. (2016) applied the Photochemical Reflectance Index (PRI) and the Normalized Difference Vegetation Index $\left(\mathrm{NDVI}_{705}\right)$ to determine discoloration and defoliation, respectively. Their results showed $\mathrm{R}^{2}$ coefficient values of 0.43 and 0.44 , with RMSE ranging from $11 \%$ to $23 \%$. The analysis was performed using satellite imagery from the beginning of July until the end of August. Jarocinska et al. (2016) showed that it was feasible to estimate the health condition of urban forests by analyzing the values of vegetation indices, defoliation and discoloration. Hanou (2010), Zhang et al. (2014), Hu et al. (2014), and Pontius et al. (2017) described the use of various datasets and methods to identify ash trees and determine their health status. The need for this kind of analysis emerged from the large scale damage caused by the activity of the emerald ash borer (EAB - Agrilus planipennis Fairmare). Hanou (2010) proved that there is a correlation between hyperspectral signatures and the level of infestation measured by the gallery counts per square meter of measured material or trunk. Zhang et al. (2014) estimated the EAB infestation stages of a single ash tree by using various types of spatial data (hyperspectral and satellite imagery). To achieve this, they used three input variables: the leaf chlorophyll content, tree crown spatial pattern, and prior knowledge. The overall accuracy (OA) was $62.5 \%$, with an omission error of $22.5 \%$, and a commission error of $18.5 \%$. Based on vegetation indices sensitive to leaf chlorophyll content, Hu et al. (2014) confirmed that the amount of chlorophyll measured by vegetation indices is capable of predicting the presence or absence of the EAB in ash trees. The OA of the binary classification used in that study (healthy/infected) was $70 \%$. It should be mentioned that the authors used a limited number of 33 ash trees for the training and test samples. The health condition of ash trees was estimated by Pontius et al. (2017), in which identification accuracy ranged from $62 \%$ (for the healthiest trees) to $22 \%$ (the sec- ond healthiest out of five classes). To reduce classification error, they developed multiple endmembers and a spectral unmixing technique to overcome the challenges posed by classification of spectrally complicated study objects situated in an urban environment. An attempt to estimate the health condition of trees from ALS was also performed by Plowright et al. (2016). Their estimates of crown density had an $\mathrm{R}^{2}$ coefficient of 0.62 for trees over 8 meters high, 0.28 for trees between 5 and $8 \mathrm{~m}$, and 0.001 for smaller trees. The authors applied a coefficient of height variation (CV) as a predictor of crown density (Tab. 2).

\section{Tree species}

The identification of tree species by RS is a complex issue due to the large diversity of species in urban areas. Trees are classified either on the single tree (object) or the pixel scale. When single tree classification is carried out, ALS- (image-)based single tree detection is usually performed first, and then segments are classified based either on spectral (image) or structural (point cloud) data, or both variables. Typically, RS data fusion is utilized for species classification. The first studies incorporating Google ${ }^{T M}$ Street View ${ }^{\circledast}$ (GSV) images have begun to appear in the literature. The global scale of the Google ${ }^{\mathrm{TM}}$ image database is expected to revolutionize the study of urban greening (Tab. S2 in Supplementary material).

In the most complex urban ecosystems, Alonzo et al. (2014) performed classification analyses of 29 dominant tree species. The study used hyperspectral imagery with ground resolution 3.4 and $3.7 \mathrm{~m}$ and ALS data with resolutions of $22 \mathrm{pts} \mathrm{m}^{-2}$. The OA of classification for the 29 dominant tree species was $83.40 \%(k=0.82)$. The application of ALS-based variables to the classification model improved the OA by approximately 4.20\%. Zhang \& Qiu (2012) classified 40 species and achieved an OA of $68.80 \%$. The difference in $O A$ values between the studies was caused in part by the different number of tree species classified, and more importantly the fact that the point clouds generated from ALS data had very different densities (22.0 vs. 3.50 pts $\mathrm{m}^{-2}$ ). Since ALS-based variables are fundamental to tree classification methods (Kaminska et al. 2018), denser point clouds provide better descriptions of tree structure and significantly improve classification results.

Voss \& Sugumaran (2008) performed classification of seven tree species using two sets of hyperspectral data from the summer and fall season, combined with ALS data. The determination of tree species was carried out using an object-oriented classification with two variants. The first variant used information from hyperspectral imagery (after minimum noise fraction, MNF, transformation), and the second used additional information from ALS (intensity and height). The OA of classification in the first variant was $48 \%$ for sum- 
Tab. 2 - Selected scientific publications reporting tree health condition using remote sensing data. (UA): user accuracy; (OA): overall accuracy; $(*)$ : Determination of health condition through variables.

\begin{tabular}{|c|c|c|c|c|c|c|c|}
\hline Publication & $\begin{array}{l}\text { Study } \\
\text { Area }\end{array}$ & Data Set & Sensor & Method & $\begin{array}{l}\text { Date of RS } \\
\text { data acqui- } \\
\text { sition }\end{array}$ & $\begin{array}{l}\text { Health } \\
\text { Condition* }\end{array}$ & Accuracy \\
\hline $\begin{array}{l}\text { Zhang et } \\
\text { al. (2014) }\end{array}$ & Canada & $\begin{array}{l}\text { DF (hyperspec- } \\
\text { tral imagery, } \\
\text { aerial imagery) }\end{array}$ & $\begin{array}{l}\text { ProSpectTIR- } \\
\text { VS2/Google } \\
\text { Earth imagery }\end{array}$ & $\begin{array}{l}\text { Vegetation indices, leaf } \\
\text { chlorophyll content, } \\
\text { longitudinal profiles, }\end{array}$ & July 2010 & $\begin{array}{l}\text { Healthy/ } \\
\text { High/medium/ } \\
\text { low condition }\end{array}$ & $62.5 \%(\mathrm{OA})$ \\
\hline $\begin{array}{l}\text { Hu et al. } \\
(2014)\end{array}$ & Canada & $\begin{array}{l}\text { DF (ALS, hyper- } \\
\text { spectral image- } \\
\text { ry) }\end{array}$ & $\begin{array}{l}9 \text { and } 4 \text { bands/ } \\
\left.\text { ALS ( } 1 \text { pts. } / \mathrm{m}^{2}\right)\end{array}$ & Individual tree crown & $\begin{array}{l}\text { 2009, ALS- } \\
\text { summer } 2007\end{array}$ & $\begin{array}{l}\text { Healthy/un- } \\
\text { healthy (1 } \\
\text { species - Ash) }\end{array}$ & $70 \%$ \\
\hline $\begin{array}{l}\text { Pontius et } \\
\text { al. (2017) }\end{array}$ & US & $\begin{array}{l}\text { DF (ALS, hyper- } \\
\text { spectral image- } \\
\text { ry, thermal im- } \\
\text { agery) }\end{array}$ & GLiHT & Segmentation & June 2006 & 4 vigor classes & $0-62 \%$ \\
\hline $\begin{array}{l}\text { Plowright } \\
\text { et al. } \\
\text { (2016) }\end{array}$ & Canada & ALS & $\begin{array}{l}\text { Leica ALS70-HP } \\
\left(25 \mathrm{pts} . / \mathrm{m}^{2}\right)\end{array}$ & $\begin{array}{l}\text { Crown density as the response } \\
\text { variable and the percentage of } \\
\text { non-ground LiDAR returns and } \\
\text { the coefficient of variation of } \\
\text { return heights as separate } \\
\text { predictor variables }\end{array}$ & April 2013 & Crown density & $\begin{array}{r}0.62\left(R^{2}\right) \text { for } \\
\text { trees in } 8 \mathrm{~m} \\
\text { to } 14 \mathrm{~m} \\
\text { height class }\end{array}$ \\
\hline $\begin{array}{l}\text { Hanou } \\
(2010)\end{array}$ & Canada & $\begin{array}{l}\text { Hyperspectral } \\
\text { imagery }\end{array}$ & ProSpectTIR-VS2 & Gallery Count / Area (DBH) & $\begin{array}{l}\text { July/August } \\
2010\end{array}$ & $\begin{array}{l}\text { Low/medium/hi } \\
\text { gh Emerald Ash } \\
\text { Borer }\end{array}$ & $0.8\left(R^{2}\right)$ \\
\hline $\begin{array}{l}\text { Malthus \& } \\
\text { Younger } \\
(2000)\end{array}$ & UK & Aerial imagery & CASI & $\begin{array}{l}\text { Correlation between: Visual } \\
\text { Stress Index (leaf colour } \times \\
\text { crown density); General Crown } \\
\text { Condition Index (crown die- } \\
\text { back } \times \text { crown density } \times \text { Leaf } \\
\text { size } \times \text { number of small dead } \\
\text { limbs); Foliage Index (foliage } \\
\text { colour } \times \text { degree of leaf } \\
\text { chlorosis } \times \text { degree of leaf } \\
\text { necrosis); Overall Tree } \\
\text { Condition Index (a combination } \\
\text { of the first threeindices prior } \\
\text { to equilibration, summed and } \\
\text { then normalised) and } \\
\text { vegetation indices }\end{array}$ & $\begin{array}{l}\text { September } \\
1996\end{array}$ & $\begin{array}{l}\text { Defoliation and } \\
\text { OTC index for } 4 \\
\text { species }\end{array}$ & $\begin{array}{l}-0.14--0.83 \\
\text { (correlation) }\end{array}$ \\
\hline $\begin{array}{l}\text { Xiao \& } \\
\text { McPherson } \\
\text { (2005) }\end{array}$ & US & Aerial imagery & Wild RC10 & Vegetation indices (NDVI) & $\begin{array}{l}\text { Summer } 2003 \\
\text { and } 2004\end{array}$ & $\begin{array}{l}\text { Classification } \\
\text { (healthy/ } \\
\text { unhealthy) }\end{array}$ & $88.9 \%$ \\
\hline $\begin{array}{l}\text { Holopainen } \\
\text { et al. } \\
\text { (2006) }\end{array}$ & Finland & Aerial imagery & - & Photointerpretation & July 2003 & $\begin{array}{l}\text { Assessing the } \\
\text { volume of trees } \\
\text { damaged as a } \\
\text { result of drought }\end{array}$ & - \\
\hline \multirow{2}{*}{$\begin{array}{l}\text { Jarocinska } \\
\text { et al. } \\
\text { (2016) }\end{array}$} & \multirow[t]{2}{*}{ Poland } & \multirow{2}{*}{$\begin{array}{l}\text { Hyperspectral } \\
\text { imagery }\end{array}$} & \multirow[t]{2}{*}{ HySpex } & \multirow{2}{*}{$\begin{array}{l}\text { Correlation with vegetation } \\
\text { indices }\end{array}$} & \multirow{2}{*}{$\begin{array}{l}\text { July and } \\
\text { August } 2015\end{array}$} & Discoloration & $0.43\left(R^{2}\right)$ \\
\hline & & & & & & Defoliation & $0.44\left(R^{2}\right)$ \\
\hline
\end{tabular}

mer data, and $45 \%$ for fall data. In the second variant with additional ALS data, the general accuracy increased to $57 \%$ and $56 \%$, respectively. A 19 percentage point increase in OA values was achieved by the incorporation of ALS data in Liu et al. (2017). However, Ghosh et al. (2014) reported no improvement in results, although they used tree heights calculated exclusively from ALS data.

Dian et al. (2016) combined hyperspectral data (10 most informative channels after MNF transformation), the Enhanced Vegetation Index (EVI), and ALS data (the normalized Digital Surface Model and segments of individual tree crowns), achieving a general classification accuracy of $79.20 \%$ $(k=0.68)$. Jarocinska et al. (2016) attempted to identify 12 tree species in the area of Bialystok (Poland). The classifica- tion was carried out on the 40 most infor- 2 data to perform a classification of 8 mative channels of hyperspectral imagery (MNF transformation), using the spectral angle mapper (SAM) method. Total classification accuracy was $78.80 \%(k=0.69)$. Pu \& Landry (2012) classified 7 tree and tree group species using IKONOS and WorldView-2 satellite imaging. The general classification accuracy for the method was $56.98 \%(k=0.48)$ based on IKONOS data, and $62.93 \%(k=0.42)$ for WorldView-2 data. The authors developed a stepwise masking protocol to distinguish between sunlit and shaded tree canopies, and they compared the accuracy of tree species mapping between four-band IKONOS imagery and three different band combinations of WorldView-2 imagery (four "traditional" bands, four additional bands, and all eight bands). Latif et al. (2012) used World-View species using the minimum distance algorithm. They achieved a user's accuracy (UA) of $0-87.2 \%$ for the individual species. Tooke et al. (2009) used QuickBird imagery and information about shaded areas obtained from ALS data. They used the decision tree classification algorithm and linear spectral mixture analysis (SMA) to distinguish between low and high vegetation, and then between coniferous and deciduous trees with different health conditions (manicured and mixed). Verlič et al. (2014) combined ALS data and satellite imagery (WorldView-2), to determine five different species using example-based feature extraction (ENVI 5 software), by applying the support vector machine (SVM) model, and achieved a UA from $12 \%$ (sweet chestnut) to $69 \%$ (Norway spruce). Tigges et al. (2013) 
Tab. 3 - Accuracy evaluation of specific tree parameters (Grade 0: no data; Grade 1: $R^{2} \leq 0.5$ or accuracy $\leq 50 \%$; Grade 2: $0.5<R^{2} \leq 0.7$ or $50 \%<$ accuracy $\leq 70 \%$; Grade 3: $0.7<R^{2}=<0.9$ or $070 \%<$ accuracy $\leq 85 \%$; Grade $4: R^{2}>0.9$ or accuracy $>85 \%$ ). The listed number of publications is reported in brackets. Last column shows the number of parameters (attributes) which could be measured using the corresponding method.

\begin{tabular}{|c|c|c|c|c|c|c|c|c|c|}
\hline Data/Method & Location & $\begin{array}{r}\text { Tree } \\
\text { height }\end{array}$ & DBH & $\begin{array}{r}\text { Crown } \\
\text { span }\end{array}$ & $\begin{array}{r}\text { Height of } \\
\text { tree crown } \\
\text { basis }\end{array}$ & $\begin{array}{r}\text { Crown } \\
\text { projection } \\
\text { surface }\end{array}$ & Species & $\begin{array}{r}\text { Health } \\
\text { condition }\end{array}$ & $\begin{array}{r}\text { Total } \\
\text { Attributes }\end{array}$ \\
\hline Aerial imagery & - & 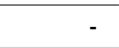 & - & - & - & - & $4(4)$ & $1-3(5)$ & $2 / 8$ \\
\hline ALS & $4(3)$ & $4(3)$ & - & - & $3(1)$ & - & $0(1)$ & $2(1)$ & $5 / 8$ \\
\hline DF (ALS, TLS/MLS) & $3(1)$ & $4(1)$ & - & - & - & $0(1)$ & - & - & $3 / 8$ \\
\hline DF (ALS, Hyperspectral imagery) & $4(3)$ & $4(2)$ & - & $4(2)$ & $4(1)$ & - & $1-4(10)$ & $2-3(3)$ & $6 / 8$ \\
\hline DF (ALS, Satellite imagery) & $3 / 4(1)$ & $3 / 4(2)$ & $3(2)$ & $4(2)$ & - & - & $1-4(2)$ & - & $5 / 8$ \\
\hline DF (TLS, ALS, Satellite imagery) & - & $4(1)$ & - & - & $2(1)$ & $3(1)$ & - & - & $3 / 8$ \\
\hline Other (GSV) & - & & - & - & - & - & $2(1)$ & - & $2 / 8$ \\
\hline Digital photographs & $4(1)$ & $4(1)$ & $4(2)$ & $4(1)$ & $4(1)$ & - & - & - & $5 / 8$ \\
\hline TLS/MLS & $4(3)$ & $4(4)$ & $4(3)$ & $4(1)$ & $4(1)$ & - & - & - & $5 / 7$ \\
\hline Satellite imagery & $3(1)$ & & - & - & - & - & $2(2)$ & - & $2 / 7$ \\
\hline
\end{tabular}

performed the classification of the eight species that are considered to be dominant in Central Europe, by testing different spectral and temporal band combinations of five RapidEye images that were collected during the vegetation season. To improve the results, they used ancillary surface and terrain models. The UA of each classification depended on the tree species and varied from $66 \%$ to $99 \%$. Berland \& Lange (2017) used GSV materials to identify tree species. In their study, a botanic specialist identified tree species based on GSV pictures, and if the identification of tree species was not possible, the type of tree was identified. Furthermore, results were compared with data from field measurements. The classification accuracy was $66 \%$ on the level of species and was $90 \%$ on the level of genus.

It is almost impossible to compare results that were obtained in different studies because there are too many differences between the study sites, the total number of species and the time when data was collected. In Xiao et al. (2004) work, a method called the Number of Categories Adjusted Index (NOCAI) was used to compare different papers. The NOCAI is calculated by dividing the accuracy that was achieved by a specific algorithm to give an expected accuracy that would be obtained if trees were randomly assigned to a species. The expected accuracy is simply $1 / k \cdot 100 \%$, where $k$ is the number of species. The NOCAI was applied to works using ALS and hyperspectral data, with the highest NOCAl value (27.52) being achieved by the algorithm developed by Zhang \& Qiu (2012). Tigges et al. (2013) reported that NOCAl values of 6.84 for studies that only used ALS and satellite data for classification. The most accurate results regarding tree species was obtained by combining hyperspectral imagery and ALS data during analysis (Zhang \& Qiu 2012, Voss \& Sugumaran 2008). As shown by previous studies, the combination of these datasets can be used to perform both pixel- and object-based classifications. A pixel-based approach enables classification results with errors from $5.10 \%$ to $18.80 \%$ (OA) to be achieved, which is better than results obtained by analyzing single format data (Liu et al. 2017). It should be noted that in a single tree crown, the leaf-level spectral reflectance may vary with leaf biochemistry and water content. Dian et al. (2016) noted that the variability in a class may be greater than between classes. For hyperspectral data this is not the case, since lower GSD data area used because of the high cost of acquisition. To obtain the best results two strategies should be implemented: either hyperspectral data (which enlarges spectral information), or multispectral data with ALS data (to compensate for the lack of spectral information), should be combined with structural information from ALS data. Hyperspectral and ALS data are currently the best possible combination of RS data for species classification.

The season in which data were obtained had an impact on the accuracy of the species classification. Voss \& Sugumaran (2008) achieved better classification results using data collected in summer $(\mathrm{OA}=$ $48 \%$ without ALS; OA $=57 \%$ with ALS) rather than in autumn (OA $=45 \%$ without ALS; OA $=56 \%$ with ALS), although the difference was small ( $3 \%$ without ALS, $1 \%$ with ALS data), and had no practical meaning. According to Liu et al. (2017), the most important parameters for detecting tree species during the spring budburst stage were the Anthocyanin Content Index and the Photochemical Reflectance Index. The most widely used classification algorithms include the SVM, the SAM, the random forest (RF), and the maximum likelihood (ML). Accurate results were generated by all algorithms, but due to the diversity of study sites, number of classified species, number of reference data used, and the fusion of various types of RS data acquired at different times of the year, it is impossible to identify which algorithm is most advantageous (Forzieri et al. 2013).

\section{Opportunities and limitations of}

individual remote sensing technologies

From the point of view of public administration, the information regarding individual tree position is one of the most important attributes acquired during inventories. Detailed location information constitutes the basis for the efficient planning of greening resources (cutting/planting), and the construction of ground and terrestrial infrastructure (Östberg et al. 2012b). The content of inventory maps produced from these data is often essential to making administrative decisions. According to the technical standards set by the Ministry of Internal Affairs and Administration in Poland regarding the execution of detailed surveys, single trees, as well as parks, squares, and lawns, are classified as Group II situational points. This classification requires that their location on maps should be specified within $0.30 \mathrm{~m}$ accuracy, in relation to geodetic control network points, before results can be added to the National Geodetic and Cartographic Database (MIAA 2011). According to published studies, it is possible to identify tree locations to this level of accuracy with TLS, but MLS and ALS data do not currently meet this requirement. Many of the tenders offered by local authorities include unspecified entries, e.g., the "identification of trees and bushes in the area of $[\ldots]$ in order to include their specific position in an inventory map" (Horbaczewska 2016). In the authors' opinion, such an entry allows the application of TLS or ALS techniques to acquire information on tree locations with an error defined in the subject literature. Tender documents (for example, in Poland) related to urban forest inventories indicate that height and crown diameters should be measured to an accuracy up to $0.50 \mathrm{~m}$ and $1.00 \mathrm{~m}$, respectively, and a breast height diameter with an accuracy of $0.01 \mathrm{~m}$. The results of the literature reviewed here show that TLS data can be used to determine all parameters with the required accuracy (Vonderach et al. 2012). MLS technology 
can be used to accurately measure crown span and height, but the accuracy required for DBH of up to a few centimeters may not be sufficient for end users (Wu et al. 2013). Zhang et al. (2015) showed that it is possible to measure tree height with an RMSE value of $1.11 \mathrm{~m}$ with ALS (calculated against field based measurements). If one takes into account the error of $0.45 \mathrm{~m}$ associated with manual field measurements, the resulting error in height measurements derived using the ALS method will be approx. $0.7 \mathrm{~m}$. In reality, this value can be lower, since high density ALS data (which is often acquired over cities) usually records heights that are very close to the real height of trees. The error will be within the range of practitioners' requirements. ALS data may also be used as an alternative source of data for crown span measurements. It is not possible to measure DBH directly using ALS methods, and assessment of DBH via indirect methods is too imprecise to constitute a substitute source of reliable data (Shrestha \& Wynne 2012). The optimal dataset therefore comprises individual tree positions and geometrical attributes obtained from terrestrial and aerial laser scanning data, tree heights obtained from ALS data, and detailed information about stem quality and precise tree location from TLS data (Tanhuanpää et al. 2014). It should be noted that no studies were found that discuss the integration of information collected by terrestrial laser scanning and airborne laser scanning. Such studies have been carried out in forest areas (Bazezew 2018), and it is likely that they could be applied successfully to urban areas.

Tree species is the most important attribute acquired during an inventory (Östberg et al. 2012b). Urban areas contain a great variety of species; typically, native tree species dominate the urban landscape, accompanied by a mixture of minor non-native species. Alonzo et al. (2014) indicated that it is possible to classify up to approximately 30 of the most numerous tree species in a given area. From a practical point of view, less numerous species should be classified into an aggregate group, i.e., deciduous/coniferous species. Therefore, substantial limitations remain in regard to the possibility of replacing the field measurement of tree species with information obtained by RS.

RS data enables tree health to be recognized with high accuracy (Xiao \& McPherson 2005). A lower accuracy is provided by methods that specify correlations between vegetation indices or variables that are calculated from a point cloud, and parameters such as defoliation or discoloration. As shown by Xiao \& MCPherson (2005), RS enables fast acquisition of information regarding the health condition of individual trees within the whole urban area. Information regarding individual trees may be used to plan cutting or replacement planting. Furthermore, the information from in- dividual pixels within crowns may determine the need for tree pruning, watering or carrying out a site survey to determine the cause of damage. Jarocinska et al. (2016) showed that the use of continuous data, such as RS data, enables greening condition to be differentiated depending on location (e.g., trees along roads are characterized by worse health condition than ones that are at a greater distance). From a practical point of view, it is more important to develop a model that could help detect the occurrence of pathogens at an early stage, so as to minimize negative effects, than to define the pre-existing effects of various factors that have caused deterioration in tree health. Comprehensive data (e.g., age and species) are needed to accurately assess the health condition of trees, and parametrize models effectively. The unavailability of such data may decrease the effectiveness of ALS data in determining tree health conditions, since for example height information from ALS can be used as a proxy for tree age. It is not possible to identify damage factors (e.g., fungal pathogens) from RS data, but it is possible to determine the general condition of trees (e.g., good, average, poor), which may constitute the basis for further field investigations. The accuracy of assessing selected tree attributes from different data sets is presented in Tab. 3. The authors evaluated the results in the literature according to the following guidelines: Grade 0: no data; Grade 1: $\mathrm{R}^{2} \leq 0.5$ or accuracy $\leq 50 \%$; Grade 2: $0.5<R^{2} \leq 0.7$ or $50 \%<$ accuracy $\leq 70 \%$; Grade 3: $0.7<\mathrm{R}^{2} \leq 0.9$ or $70 \%<$ accuracy $\leq 85 \%$; Grade $4: \mathrm{R}^{2}>0.9$ or accuracy $>85 \%$. The compatibility of information from different data sets constitutes the other factor to be considered when selecting RS data for inventories.

In studies that applied data fusion, the authors, depending on the purpose of their studies, did not always have to assess all of the attributes that are listed in Tab. 3. Therefore, based on the results of this literature review and the compatibilities of individual data items, it can be concluded that complete information regarding the eight listed attributes may be obtained using terrestrial or airborne laser scanning and airborne photography (hyperspectral). Data selection should also depend on field based data and available financial resources. Holopainen et al. (2013) suggested that TLS measurements, due to their cost and labor consumption, should be performed only in environmentally significant areas, where a more accurate assessment of tree parameters other than location is required. The application of MLS is reasonable for trees that are growing in the vicinity of roads or in parks. Airborne data should be collected to compile inventories over the area of a district or a city.

Remote sensing data collection methods have their limits. Above all, the data are relatively expensive and require sophisticated methods of processing by specialists. Pub- lic administration in city level currently lacks the specialists and software which allow large datasets to be processed automatically. Many of the publications in this review use sophisticated, bespoke processing techniques which are not available as user-friendly software. This is a major constraint on the application of more sophisticated processing and implementation of such technologies to facilitate the determination of more detailed characteristics of single trees. The need for specialist processing results in not only the costs of acquisition, but also data processing costs, being higher, as well as study lengths being longer. The most expensive data are those which enable the highest measurement precision; that is, TLS and MLS. Airborne or satellite data acquisition techniques make it possible to analyze large areas, but the precision of such research is lower (Holopainen et al. 2013).

The ideal remote sensing technique for data acquisition is dependent on the scale of the analysis. In the case of urban vegetation, the optimal scale of analysis is a single tree, however, many works are performed throughout cities to determine vegetation cover (Gupta et al. 2012, Mincey et al. 2013, Ucar et al. 2016). Taking into the account the shape and size of tree crowns in urban environments, it is difficult to constrain an optimal ground sample distance for a defined area. In the aforementioned literature, the data densities range from several to several dozens of points per square meter, and spectral data resolution from several dozens of centimeters to dozens of meters. Myint et al. (2011) suggested that pixel size used to classify objects should be at least half the size of the object, as too many small pixels for a single large object causes large spectral change, making it more difficult to classify the object.

Atmospheric conditions can pose a problem to remote sensing techniques. Remote sensing data acquisition, in order to be useful, must be carried out in optimal light conditions, ideally without wind and with no cloud cover (Ju \& Roy 2008). In many countries (e.g., Poland) such days, when data acquisition is possible, are limited (30$40 \%$ of the year). Cloud cover can make it impossible to acquire data for several weeks. This can have significant negative impacts, considering that in order to acquire accurate classification results, most images need to be acquired in the vegetation period, which only lasts a few months a year.

The remote sensing data market does not appear ready to carry out surveys for a large number of towns, especially if multitemporal analyses are being considered. Data is acquired at much greater effort in multi-temporal analyses, and much bigger datasets are acquired from single flights. This prolongs the time required for data processing, and thus the research output. In a country with several dozens of big cities, it is practically impossible to acquire 
RS data more often than once a year for a single city. The ability to collect such data depends on the remote sensing services market in any particular country, the number and availability of hyperspectral scanners, and many other factors related to the acquisition of remote sensing data.

\section{Conclusions}

The use of remote sensing data makes it possible to determine the characteristics of urban vegetation at various levels of detail and at different scales. The accuracy of analyses depend on the type and quality of the RS data used, and the environment in which the analyses were carried out.

Laser scanning is a technology that collects the most versatile RS data on the characteristics of trees. TLS has the highest precision of measurement, while ALS has the largest operating system.

Spectral data, in particular hyperspectral data, allow the classification of up to several dozen species of tree in urban areas. The integration of many datasets, particularly spectral data (aerial images and satellite images) and structural data (LIDAR), facilitates the most complex use of RS data and helps to improve tree species classification estimates.

To estimate the largest possible number of significant parameters from RS data, it is necessary to apply data that have been integrated from multiple sources.

The most important research challenges in urban vegetation monitoring (apart from the development of data processing and data integration methods) are identified as refining species classification methods, tree segmentation methods, and methods of determining specific tree characteristics. There are no studies on these topics that have been performed on large datasets, carried out on a wide geographic scale or on a homogeneous set of remote sensing data.

Despite the fact that this review summarized and attempted to compare the results of the different methods and technologies used in the estimation of tree features and species, it is difficult to state clearly which of them are the most accurate. This is mainly due to the enormous variety of data usage, processing methods, ground data volumes and methods of integrating different types of remote sensing data.

At the moment, no "best practice" methodologies for the use of RS in urban forestry do exist. Such guidelines would address issues such as the selection of RS data for specific purposes, or the technical specifications necessary to achieve particular objectives. In addition, there are no dedicated user-friendly applications designed for the use of civil servants, who do not necessarily have extensive knowledge about remote sensing, but are responsible for acquiring spatial information.

\section{Acknowledgements}

This article was written under the project (281502 and 240412) financed by the Polish Ministry of Science and Higher Education.

\section{References}

Abd-Elrahman A, Thornnill $M$, Andreu $M$, Escobedo $F$ (2010). A community-based urban forest inventory using online mapping services and consumer-grade digital images. International Journal of Applied Earth Observation and Geoinformation 12: 249-260. - doi: 10.1016/j.jag. 2010.03.003

Alonzo M, Bookhagen B, Roberts D (2014). Urban tree species mapping using hyperspectral and lidar data fusion. Remote Sensing of Environmental 148: 70-83. - doi: 10.1016/j.rse.2014. 03.018

Alonzo M, McFadden J, Nowak D, Roberts D (2016). Mapping urban forest structure and function using hyperspectral imagery and lidar data. Urban Forestry and Urban Greening 17: 135-147. - doi: 10.1016/j.ufug.2016.04.003

Anderson L, Cordell H (1988). Influence of trees on residential property values in Athens Georgia (USA): a survey based on actual sales prices. Landscape and Urban Planning 15 (1-2): 153-164. - doi: 10.1016/0169-2046(88)90023-0 Ardila J, Bijker W, Tolpekin V, Stein A (2012). Context-sensitive extraction of tree crown objects in urban areas using VHR satellite images. International Journal of Applied Earth Observation and Geoinformation 15: 57-69. - doi: 10.1016/j. jag.2011.06.005

Banskota A, Kayastha N, Falkowski M, Wulder M, Forese R, White J (2014). Forest monitoring using Landsat time series data: a review. Canadian Journal of Remote Sensing 40 (5): 362384. - doi: 10.1080/07038992.2014.987376 Banzhaf E, Kollai H (2015). Monitoring the urban tree cover for urban ecosystem services - The case of Leipzig, Germany. In: Proceedings of the " $36^{\text {th }}$ International Symposium on Remote Sensing of Environment", Berlin (Germany) 1115 May 2015. ISPRS - International Archives of the Photogrammetry, Remote Sensing and Spatial Information Sciences XL-7/W3: 301-305. doi: 10.5194/isprsarchives-XL-7-W3-301-2015

Bazezew M (2018). Integrating airborne LiDAR and terrestrial laser scanner forest parameters for accurate above-ground biomass/carbon estimation in Ayer Hitam tropical forest, Malaysia. International Journal of Applied Earth Observation and Geoinformation 73: 638-652. doi: 10.1016/j.jag.2018.07.026

Bentsen P, Lindholst A, Konijnendijk CC (2010). Reviewing eight years of urban forestry and urban greening: taking stock, looking ahead. Urban Forestry and Urban Greening 9 (4): 273280. - doi: 10.1016/j.ufug.2010.06.003

Berland A, Lange D (2017). Google Street View shows promise for virtual street tree surveys. Urban Forestry and Urban Greening 21: 11-15. doi: 10.1016/j.ufug.2016.11.006

Bickmore CJ, Hall T (1983). Computerisation of tree inventories. AB Academic Publisher, Berkhamsted, UK.

Brack CL (2006). Updating urban forest inventories: an example pf the DISMUT model. Urban Forestry and Urban Greening 5: 189-194. - doi: 10.1016/j.ufug.2006.09.001
Chi M, Plaza A, Benediktsson J, Sun Z, Shen J, Zhu $Y$ (2016). Big data for remote sensing: challenges and opportunities. Proceedings of the IEEE 104 (11): 2207-2219. [online] URL: https:// ieeexplore.ieee.org/abstract/document/756563 4

Clarke L, Jenerette D, Davila A (2013). The luxury of vegetation and the legacy of tree biodiversity in Los Angeles, CA. Landscape and Urban Planning 116: 48-59. - doi: 10.1016/j.landurbplan. 2013.04.006

Cumming A, Galvin M, Rabaglia R, Cumming J, Twardus D (2001). Forest health monitoring protocol applied to roadside trees in Maryland. Journal of Arboriculture 27 (3): 126-138. [online] URL: http://www.researchgate.net/publication/ 242076654

Cumming A, Twardus D, Nowak D (2008). Urban forest health monitoring: large-scale assessments in the United States. Arboriculture and Urban Forestry 34 (6): 341-346. [online] URL: http://www.fs.usda.gov/treesearch/pubs/19525 Dian Y, Pang Y, Dong Y, Li Z (2016). Urban tree species mapping using airborne LiDAR and hyperspectral data. Journal of the Indian Society of Remote Sensing 44 (4): 595-603. - doi: 10.1007/s12524-015-0543-4

Escobedo F, Andreu M (2008). A community guide to urban forest inventories. IFAS Extension, University of Florida, Gainesville, FL, USA, pp. 1-4. [online] URL: http://journals.flvc.org/ edis/article/view/117190

Forzieri G, Tanteri L, Moser G, Catani F (2013). Mapping natural and urban environments using airborne multi-sensor ADS40-MIVIS-LiDAR synergies. International Journal of Applied Earth Observation and Geoinformation 23: 313-323. doi: 10.1016/j.jag.2012.10.004

Franke J, Roberts D, Halligan K, Menz G (2009). Hierarchical Multiple Endmember Spectral Mixture Analysis (MESMA) of hyperspectral imagery for urban environments. Remote Sensing of Environmental 113: 1712-1723. - doi: 10.1016/j. rse.2009.03.018

Ghosh A, Fassnacht F, Joshi PK, Koch B (2014). A framework for mapping tree species combining hyperspectral and LiDAR data: role of selected classifiers and sensor across three spatial scales. International Journal of Applied Earth Observation and Geoinformation 26: 49-63. doi: 10.1016/j.jag.2013.05.017

Giles-Corti B, Broomhall M, Knuiman M, Collins C, Douglas K, Ng K, Lange A, Donovan R (2005). Increasing walking: how important is distance to, attractiveness, and size of public open space? American Journal of Preventive Medicine 28: 169-176. - doi: 10.1016/j.amepre.2004.10. 018

Gill SJ, Biging GS, Murphy EC (2000). Modelling conifer tree crown radius and estimating canopy cover. Forest Ecology and Management 126: 2416-2433. - doi: 10.1016/S0378-1127(99)oo1 $13-9$

Gupta K, Kumar P, Pathan SK, Sharma KP (2012). Urban neighbourhood green index - a measure of green spaces in urban areas. Landscape and Urban Planning 105: 325-335. - doi: 10.1016/j.land urbplan.2012.01.003

Hanou I (2010). 2010 Town of Oakville hyperspectral EAB analysis. Town of Oakville Parks and Open Space, Denver, CO, USA, pp. 9. 
Holopainen $M$, Leino $O$, Kämäri $H$, Talvitie $M$ (2006). Drought damage in the park forests of the city of Helsinki. Urban Forestry and Urban Greening 4: 75-83. - doi: 10.1016/j.ufug.2005.11. 002

Holopainen M, Kankare V, Vastaranta M, Liang X, Lin $Y$, Vaaja M, Yu $X$, Hyyppä J, Hyyppä $H$, Kaartinen $H$ (2013). Tree mapping using airborne, terrestrial and mobile laser scanning: a case study in a heterogeneous urban forest. Urban Forestry and Urban Greening 12: 546-553. doi: 10.1016/j.ufug.2013.06.002

Horbaczewska J (2016). Wykonanie inwentaryzacji dendrologicznej wybranych terenów zieleni miasta Kolobrzeg oraz ekspertyzy dendrologicznej wskazanych egzemplarzy drzew [Making a dendrological inventory of selected green areas of the city of Kolobrzeg and dendrological expertise of selected specimens of trees]. Documents of City of Kolobrzeg, Poland, pp. 5-6. [in Polish]

Hu B, Li J, Wang J, Hall B (2014). The early detection of the Emerald Ash Borer (EAB) using advanced geospatial technologies. In: Proceedings of the "ISPRS Technical Commission II Symposium”, Toronto (Canada) 6-8 Oct 2014. The International Archives of the Photogrammetry, Remote Sensing and Spatial Information Sciences, vol XL-2, pp. 213-219. [online] URL: http://www.int-arch-photogramm-remote-sensspatial-inf-sci.net/XL-2/213/2014/isprsarchives-X L-2-213-2014.pdf

Höfle B, Hollaus M, Hagenauer J (2012). Urban vegetation detection using radiometrically calibrated small-footprint full-waveform airborne LiDAR data. ISPR Journal of Photogrammetry and Remote Sensing 67: 134-147. - doi: 10.1016/j. isprsjprs.2011.12.003

Iovan C, Boldo D, Cord M (2008). Detection, characterization, and modeling vegetation in urban areas from high-resolution aerial imagery. IEEE Journal of Selected Topics in Applied Earth Observations and Remote Sensing 1 (3): 206-213. - doi: 10.1109/JSTARS.2008.2007514 Jarocinska A, Robak A, Kopeć D, Niedzielko J, Slawik L, Ochtyra A, Marcinkowska-Ochtyra A, Zagajewski B, Walesiak J (2016). Ocena i monitorowanie stanu zieleni miejskiej badana metodami teledetekcyjnymi. Informacja o efektywnosci funkcjonowania przestrzeni zielonej w miescie [Assessment and monitoring of the urban greenery condition by remote sensing methods. Information on the effectiveness of green space in the city]. In: Proceedings of the "Information Environment Conference". Warsaw (Poland) 21-22 Nov 2016. Ekoportal, Poland, pp. 13-14. [in Polish]

Ju J, Roy D (2008). The availability of cloud-free Landsat ETM+ data over the conterminous United States and globally. Remote Sensing of Environment 112: 1196-1211. - doi: 10.1016/j.rse.20 07.08.011

Kaartinen H, Hyyppä J, Yu X, Vastaranta M, Hyyppä H, Kukko A, Holopainen M, Heipke C, Hirschugl M, Morsdorf F, Naesset E, Pitkänen J, Popescu S, Solberg S, Bernd M, Wu J (2012). An international comparison of individual tree detection and extraction using airborne laser scanning. Remote Sensing 4 (4): 950-974. - doi: $10.3390 /$ rs4040950

Kaminska A, Sterenczak K, Lisiewicz M, Kras- zewski B, Sadkowski R (2018). Species-related single dead tree detection using multi-temporal ALS data and CIR imagery. Remote Sensing of Environment 219: 31-43. - doi: 10.1016/j.rse.2018. 10.005

Keller J, Konijnendijk CC (2012). A comparative analysis of municipal urban tree inventories of selected major cities in North America and Europe. Arboriculture and Urban Forestry 38 (1): 24-30. [online] URL: http://www.researchgate. net/publication/280562670

Kempeneers P, Soille P (2017). Optimizing Sentinel-2 image selection in a big data context. Big Earth Data 1 (1-2): 145-158. - doi: 10.1080/209 64471.2017.1407489

Kerr J, Sallis J, Saelens B, Cain K, Conway T, Frank L, King A (2012). Outdoor physical activity and self-rated health in older adults living in two regions of the US. International Journal of Behavioral Nutrition and Physical Activity 9 (1): 89. - doi: 10.1186/1479-5868-9-89

Konijnendijk CC, Ricard R, Kenney A, Randrup T (2006). Defining urban forestry - A comparative perspective of North America and Europe. Urban Forestry and Urban Greening 4 (3-4): 93103. - doi: 10.1016/j.ufug.2005.11.003

Kronenberg J (2012). Bariery dla utrzymania drzew w miastach i sposoby pokonywania tych barier [Barriers for maintaining trees in cities and ways to overcome these barriers]. Zrównowazony rozwój - zastosowania 3 (2012): 3149. [in Polish]

Lamprecht S, Stoffels J, Dotzler S, Ha E, Udelhoven T (2012). aTrunk - An ALS-based trunk detection algorithm. Remote Sensing 7 (8): 99759997. - doi: 10.3390/rs70809975

Latif Z, Zamri I, Omar H (2012). Determination of tree species using Woldview-2 data. In: Proceedings of the "IEEE $8^{\text {th }}$ International Colloquium on Signal Processing and its Applications". Melaka (Malaysia), 23-25 Mar 2012. IEEE Explore Digital Library, Piscataway, NJ, USA, pp. 383-387. - doi: 10.1109/CSPA.2012.6194754

Lee J-H, Ko Y, McPherson E (2016). The feasibility of remotely sensed data to estimate urban tree dimensions and biomass. Urban Forestry and Urban Greening 16: 208-220. - doi: 10.1016/j.ufu g.2016.02.010

Liu L, Coops N, Aven N, Pang Y (2017). Mapping urban tree species using integrated airborne hyperspectral and LiDAR remote sensing data. Remote Sensing of Environmental 200: 170-182. doi: 10.1016/j.rse.2017.08.010

Malthus T, Younger C (2000). Remote sensing stress in street trees using high spatial resolution data. In: Proceedings of the "2nd International Geospatial Information in Agriculture and Forestry Conference". Lake Buena Vista (FL, USA) 10-12 Jan 2000. pp. 326-333.

Maruthaveeran S, Yaman A (2010). The identification of criteria and indicators to evaluate hazardous street trees of Kuala Lumpur, Malaysia: a Delphi study. Journal of Forestry 108 (7): 360364. [online] URL: http://academic.oup.com/ jof/article/108/7/360/4598924

McPherson E, Nowak D, Heisler G, Grimmond S, Souch C, Grant R, Rowntree R (1997). Quantifying urban forest structure, function, and value: the Chicago Urban Forest Climate Project. Urban Ecosystems 1 (1): 49-61. - doi: 10.1023/A:1014 350822458
MIAA (2011). Regulation of the Minister of Internal Affairs and Administration of November 9, 2011 on technical standards of performing detailed surveys and working out and sending results of these surveys to National Geodetic and Cartographic Database. Journal of Laws No. 263, item 1572, Dziennik Ustaw Rzeczypospolitej Polskiej, Warsaw, Poland.

Mielcarek M, Balazy R, Zawila-Niedzwiecki T (2015). Comparison of the accuracy of remote methods tree-height estimation. Sylwan 159 (9): 714-721.

Mielcarek M, Sterenczak K, Khosravipour A (2018). Testing and evaluating different LiDAR derived canopy height model generation methods for tree height estimation. International Journal of Applied Earth Observation and Geoinformation 71: 132-143. - doi: 10.1016/j.jag.2018. 05.002

Miller R (1997). Urban forestry: planning and managing urban green spaces $\left(2^{\text {nd }}\right.$ edn). Prentice Hall, New Jersey, USA, pp. 4-8.

Mincey S, Schmitt-Harsh M, Thurau R (2013). Zoning, land use, and urban tree canopy cover: the importance of scale. Urban Forestry and Urban Greening 12: 191-199. - doi: 10.1016/j.ufug. 2012.12.005

Morgenroth J, Gomez C (2014). Assessment of tree structure using a 3D image analysis technique - a proof of concept. Urban Forestry and Urban Greening 13: 198-203. - doi: 10.1016/j.ufug. 2013.10.005

Morsdorf F, Frey O, Meier E, Itten K, Allgöwer B (2008). Assessment of the influence of flying altitude and scan angle on biophysical vegetation products derived from airborne laser scanning. International Journal of Remote Sensing 29 (5): 1387-1406. - doi: 10.1080/01431160701736349

Moskal M, Zheng G (2012). Retrieving forest inventory variables with terrestrial laser scanning (TLS) in urban heterogeneous forest. Remote Sensing 4: 1-20. - doi: 10.3390/rs4010001

Muthulingam U, Thangavel S (2012). Density, diversity and richness of woody plants in urban green spaces: a case study in Chennai metropolitan city. Urban Forestry and Urban Greening 11: 450-459. - doi: 10.1016/j.ufug.2012.08.003 Myint S, Gober P, Brazel A, Grossman-Clarke S, Weng Q (2011). Per-pixel vs. object-based classification of urban land cover extraction using high spatial resolution imagery. Remote Sensing of Environment 115: 1145-1161. - doi: 10.1016/j. rse.2010.12.017

Nielsen A, Östberg J, Delshammar T (2014). Review of urban tree inventory methods used to collect data at single-tree level. Arboriculture and Urban Forestry 40 (2): 96-111. [online] URL: http://www.researchgate.net/publication/2860 00702

Nowak D, Heisler G (2010). Air quality effects of urban trees and parks. National Recreation and Park Association, Ashburn, VA, USA, pp. 6. [online] URL: http://www.fs.usda.gov/treesearch/ pubs/52881

Nowak D, Noble N, Sisinni S, Dwyer J (2001). People and trees assessing the US urban forest resource. Journal of Forestry 99 (3): 37-42. [online] URL: http://academic.oup.com/jof/article/ 99/3/37/4614357

Nowak D, Crane D, Stevens J (2006). Air pollution removal by urban trees and shrubs in the 
United States. Urban Forestry and Urban Greening 4: 111-123. - doi: 10.1016/j.ufug.2006.01. 007

Olofsson K, Holmgren J, Olsson H (2014). Tree stem and height measurements using terrestrial laser scanning and the RANSAC algorithm. Remote Sensing 6 (5): 4323-4344. - doi: 10.339 o/rs6054323

Orka H, Bollandsås O (2010). Effects of different sensors and leaf-on and leaf-off canopy conditions on echo distributions and individual tree properties derived from airborne laser scanning. Remote Sensing of Environment 114 (7): 1445-1461. - doi: 10.1016/j.rse.2010.01.024

Östberg J, Delshammar T, Fransson A, Nielsen A (2012a). Standard for tree inventories in urban environments. Department of Landscape Management, Design and Construction, Alnarp, Sweden, pp. 4-7.

Östberg J, Martinsson M, Stål O, Fransson A (2012b). Risk of root intrusion by tree and shrub species into sewer pipes in Swedish urban areas. Urban Forestry and Urban Greening 1: 6571. - doi: 10.1016/j.ufug.2011.11.001

Östberg J, Delshammar T, Wiström B, Nielsen A (2013). Grading of parameters for urban tree inventories by city officials, arborists, and academics using the Delphi method. Environmental Management 51: 694-708. - doi: 10.1007/soo2 67-012-9973-8

Patterson M, Wiseman E, Winn M, Lee S-M, Araman $P$ (2011). Effects of photographic distance on tree crown attributes calculated using UrbanCrowns image analysis software. Arboriculture and Urban Forestry 37 (4): 137-179. [online] URL: http://www.fs.usda.gov/treesearch/pubs/ 39433

Phu La H, Dam Eo Y, Chang A, Kim CH (2015). Extraction of individual tree crown using hyperspectral image and LiDAR data. KSCE Journal of Civil Engineering 19 (4): 1078-1087. - doi: 10.1007/s12205-013-1178-z

Plowright A, Coops N, Eskelson B, Sheppar S, Aven $N$ (2016). Assessing urban tree condition using airborne light detection and ranging. Urban Forestry and Urban Greening 19: 140-150. doi: 10.1016/j.ufug.2016.06.026

Pontius J, Hanavan R, Hallett R, Cook B, Corp L (2017). High spatial resolution spectral unmixing for mapping ash species across urban environment. Remote Sensing of Environment 199: 360-369. - doi: 10.1016/j.rse.2017.07.027

Popescu SC, Wynne RH, Nelson RF (2003). Measuring infividual tree crown diameter with LiDAR and assessing its influence on estimating forest volume and biomass. Canadian Journal of Remote Sensing 29: 564-577. - doi: 10.5589/m 03-027

Pu R, Liu D (2011). Segmented canonical discriminant analysis of in situ hyperspectral data for identifying 13 urban tree species. International Journal of Remote Sensing 32: 2207-2226. - doi: $10.1080 / 01431161003692040$

Pu R, Landry S (2012). A comparative analysis of high spatial resolution IKONOS and WorldView2 imagery for mapping urban tree species. Remote Sensing of Environment 124: 516-533. doi: 10.1016/j.rse.2012.06.011

Pueschel P, Newnham G, Rock G, Udelhoven T, Werner W, Hill J (2013). The influence of scan mode and circle fitting on tree stem detection, stem diameter and volume extraction from terrestrial laser scans. ISPRS Journal of Photogrammetry and Remote Sensing 77: 44-56. doi: 10.1016/j.isprsjprs.2012.12.001

Pullin A, Stewart G (2006). Guidelines for systematic review in conservation and environmental management. Conservation Biology 20 (6): 1647-1656. - doi: 10.1111/j.1523-1739.2006.00 485.x

Putut Ash Shidiq I, Wibowo A, Kusratmoko E, Indratmoko S, Ardhianto R, Prasetyo Nugroho B (2017). Urban forest topographical mapping using UAV Lidar. In: Proceedings of the " 5 " Geoinformation Science Symposium (GSS 2017)”. Yogyakarta (Indonesia) 27-28 Sept 2017. IOP Conference Series: Earth and Environmental Science 98: 012034. - doi: 10.1088/1755-1315/98/ $1 / 012034$

Rahman M, Rashed T (2015). Urban tree damage estimation using airborne laser scanner data and geographic information systems: an example from 2007 Oklahoma ice storm. Urban Forestry and Urban Greening 14: 562-572. - doi: 10.1016/j.ufug.2015.05.008

Randrup T, Konijnendijk CC, Dobbertin M, Prüller $R$ (2005). The concepts of urban forestry in Europe. In: "Urban Forests and Trees" (Konijnendijk CC, Nilsson K, Randrup TB, Schipperijn J eds). Springer, Berlin, Heidelberg, pp. 9-21. doi: 10.1007/3-540-27684-X_2

Rutzinger M, Pratihast A, Elberink S (2011). Tree modeling from mobile laser scanning data-sets. The Photogrammetric Record 26 (135): 361-372. - doi: 10.1111/j.1477-9730.2011.00635.x

Saarinen N, Vastaranta M, Kankare V, Tanhuanpää T, Holopainen M, Hyyppä J, Hyyppä H (2014). Urban-tree-attribute update using multisource single-tree inventory. Forests 5: 10321052. - doi: $10.3390 /$ 5051032

Shrestha R, Wynne R (2012). Estimating biophysical parameters of individual trees in an urban environment using small footprint discret-return imaging Lidar. Remote Sensing 4: 484-508. doi: $10.3390 /$ rs4020484

Sjöman H, Östberg J, Bühler O (2012). Diversity and distribution of the urban tree population in ten major Nordic cities. Urban Forestry and Urban Greening 11 (1): 1-39. - doi: 10.1016/j.ufug.20 11.11.002

Sobczynski L, Sitarski M, Stawowska-Carewicz N, Pstragowska M (2011). Inventory of green areas on the example of Warsaw and Gliwice - field measurements. Czlowiek i Srodowisko 35 (3-4): 123-132.

Sterenczak K, Bedkowski K, Weinacker H (2008). Accuracy of crown segmentation and estimation of selected trees and forest stand parameters in order to resolution of used DSM and nDSM models generated from dense small footprint LIDAR data. The International Archives of the Photogrammetry, Remote Sensing and Spatial Information Sciences, Youth Forum, vol. XXXVIII, Part B6b, pp. 27-33. [online] URL: http://www.isprs.org/proceedings/xxxvii/ congress/6b_pdf/05.pdf

Sterenczak K (2013). Czynniki warunkujace proces detekcji pojedynczych drzew w oparciu o dane pozyskane w wyniku lotniczego skanowania laserowego [Factors influencing individual tree crowns detection based on airborne laser scanning data]. Lesne Prace Badawcze 74 (4):
323-333. [in Polish]

Stigsdotter U, Ekholm O, Schipperijn J, Toftager M, Kamper-Jorgensen F, Randrup T (2010). Health promoting outdoor environments - associations between green space, and health, health related quality of life and stress based on a Danish national representative survey. Scandinavian Journal of Public Health 38: 411417. - doi: $10.1177 / 1403494810367468$

Strunk J, Mills J, Ries P, Temesgen H, Jeroue L (2016). An urban forest-inventory-and-analysis investigation in Oregon and Washington. Urban Forestry and Urban Greening 18: 100-109. doi: 10.1016/j.ufug.2016.04.006

Takebayashi H, Moriyama M (2007). Surface heat budget on green roof and high reflection roof for mitigation of urban heat island. Building and Environment 42: 2971-2979. - doi: 10.1016/j. buildenv.2006.06.017

Tanhuanpää T, Vastaranta M, Kankare V, Holopainen M, Hyppä J, Hyppä H, Alho P, Raisio J (2014). Mapping of urban roadside trees - A case study in the tree register update process in Helsinki city. Urban Forestry and Urban Greening 13: 562-570. - doi: 10.1016/j.ufug.2014. 03.005

Tate R (1985). Uses of street tree inventory data. Journal of Arboriculture 11 (7): 210-213.

Thaiutsa B, Puangchit L, Kjelgren R, Arunpraparut W (2008). Urban green space, street tree and heritage large tree assessment in Bangkok, Thailand. Urban Forestry and Urban Greening 7: 219-229. - doi: 10.1016/j.ufug.2008.03.002

Tigges J, Lakes T, Hostert P (2013). Urban vegetation classification: benefits of multitemporal RapidEye satellite data. Remote Sensing of Environment 136: 66-75. - doi: 10.1016/j.rse.2013. 05.001

Tompalski P (2009). Naziemny skaning laserowy w inwentaryzacji zieleni miejskiej na przykladzie plant w Krakowie [Terrestrial laser scanning for an urban green inventory]. Archiwum Fotogrametrii, Kartografii i Teledetekcji 20: 421431. [in Polish]

Tompalski P (2013). Wykorzystanie technik geomatycznych $w$ inwentaryzacji szaty roslinnej obszarów poprzemyslowych Krakowa w aspekcie ich rewitalizacji [The use of geomatic techniques in the inventory of plant cover of post-industrial areas in Krakow in the aspect of their revitalization]. PhD thesis, Wydzial Lesny, Katedra Ekologii Lasu, Uniwersytet Rolniczy im. Hugona Kollataja, Poland, pp. 127-155. [in Polish]

Tooke T, Coops N, Goodwin N, Voogt J (2009). Extracting urban vegetation characteristics using spectral mixture analysis and decision tree classifications. Remote Sensing of Environment 113: 398-407. - doi: 10.1016/j.rse.2008.10.005 Ucar Z, Bettinger P, Merry K, Siry J, Bowker JM, Akbulut R (2016). A comparison of two sampling approaches for assessing the urban forest canopy cover from aerial photography. Urban Forestry and Urban Greening 16: 221-230. - doi: 10.1016/j.ufug.2016.03.001

UNRI (2010). A field guide standards for urban forestry data collection. Draft 2.0, Web site. [online] URL: http://www.unri.org/standards/? page_id=2

Verlič A, Durič N, Kokalj Z, Marsetič A, Simončič P, Oštir K (2014). Tree species classification us- 
ing Worldview-2 satellite images and laser scanning data in a natural urban forest. Prethodno priopćenje - Preliminary communication. Šumarski list 9-10: 477-488.

Vonderach C, Voegtle T, Adler P (2012). Voxelbased approach for estimating urban tree volume from terrestrial laser scanning data. In: Proceedings of the "XXII ISPRS Congress". Melbourne (Australia) 25 Aug - 1 Sept 2012. ISPRS International Archives of the Photogrammetry, Remote Sensing and Spatial Information Sciences XXXIX-B8: 451-456. - doi: 10.5194/isprsarc hives-XXXIX-B8-451-2012

Voss M, Sugumaran R (2008). Seasonal effect on tree species classification in an urban environment using hyperspectral data, LiDAR, and an object- oriented approach. Sensors 8: 30203036. - doi: 10.3390/s8053020

Wu B, Yu B, Yue W, Shu S, Tan W, Hu Ch Huang Y, $\mathrm{Wu}$ J, Liu H (2013). A voxel-based method for automated identification and morphological parameters estimation of individual street trees from mobile laser scanning data. Remote Sensing 5: 584-611. - doi: 10.3390/rs5020584 Wulder M, White J, Loveland T, Woodcock C, Belward A, Cohen W, Fosnight E, Shaw J, Masek J, Roy D (2016). The global Landsat archive: status, consolidation and direction. Remote Sensing of Environment 185: 271-283. - doi: 10.1016/j. rse.2015.11.032
Xiao Q, McPherson E (2005). Tree health mapping with multispectral remote sensing data at UC Davis, California. Urban Ecosystems 8: 349361. - doi: 10.1007/s11252-005-4867-7

Xiao Q, Ustin SL, McPherson EG (2004). Using AVIRIS data and multiple-masking techniques to map urban forest tree species. International Journal of Remote Sensing 25: 5637-5654. - doi: 10.1080/01431160412331291224

Yu X, Hyppa J, Huppa H, Maltamo M (2004). Effects of flight altitude on tree height estimation using airborne laser scanning. In: Proceedings of the "ISPRS working group VIII/2". Freiburg (Germany) Oct 3-6 2004. The International Archives of the Photogrammetry, Remote Sensing and Spatial Information Sciences 36 (8/W2): 96-101.

Zhang K, Hu B (2012). Individual urban tree species classification using very high spatial resolution airborne multi-spectral imagery using longitudinal profiles. Remote Sensing 4: 17411757. - doi: 10.3390/rs4061741

Zhang C, Qiu F (2012). Mapping individual tree species in an urban forest using airborne lidar data and hyperspectral imagery. Photogrammetric Engineering and Remote Sensing 78 (10): 1079-1087. - doi: 10.14358/PERS.78.10.1079

Zhang K, Hu B, Robinson J (2014). Early detection of emerald ash borer infestation using multisourced data: a case study in the town of
Oakville, Ontario, Canada. Journal of Applied Remote Sensing 8 (1): 083602. - doi: 10.1117/1. JRS.8.083602

Zhang C, Zhou Y, Qiu F (2015). Individual tree segmentation from LiDAR point clouds for urban forest inventory. Remote Sensing 7: 78927913. - doi: 10.3390/rs70607892

Zupancic T, Westmacott C, Bulthius M (2015). The Impact of green space on heat and air pollution in urban communities: a meta-narrative systematic review. David Suzuki Foundation, Vancouver, BC, Canada, pp. 68.

Zygmunt R, Banas J, Zieba S (2014). Urban forests stability on the example of "Las Wolski" in Cracow. Proceedings of the Center for Nature and Forestry Education 16 (39): 106-119.

\section{Supplementary Material}

Fig. S1 - Number of publications in ScienceDirect $^{\circledR}$ (keywords: "Forest", "Remote sensing").

Tab. S1 - Selected scientific publications using remote sensing data to tree species classification.

Link: Ciesielski_3024@supplo01.pdf 